\title{
Government Behavior in the Development of Inclusive Finance in China from the Perspective of Historical Institutionalism: Regulation or Boost? Based on international case comparison
}

\author{
Yang Wang ${ }^{1, a, *}$ \\ ${ }^{1}$ School of Government, Beijing normal University, China \\ a17301090619@163.com \\ ${ }^{*}$ Corresponding author
}

Keywords: Inclusive finance; Historical institutionalism; Government behavior;

\begin{abstract}
In recent years, the inclusive financial industry has become a key development industry of China. The central bank and government departments continuously increased its importance through policy support and achieved China's inclusive finance steady development. As with all economic propositions, it is often controversial that the government's policy behavior in the financial market, especially against the backdrop of creating a more inclusive industry, tends to be either forced intervention or flexible management. However, it is noteworthy that the content of inclusive financial policy is dynamic. Though its standard dimension does not fulfil the final need to advance development of inclusive finance, we may forecast the future trend of China's inclusive finance initiatives by comparing the focuses and characteristics of policies in different countries under the global wave of inclusive finance activities.
\end{abstract}

\section{Introduction}

Historical institutionalism believes that any institution is created to solve problems in current economic and social development, and has stability at a certain point in history, and will not be easily changed by subsequent changes of the environment, and will exert a restrictive effect on the subsequent policy choices. Therefore, its continuation and change evidence should be find in the historical background and reality of its creation. Meanwhile, the formation and change of any institution is carried out in a specific specific cultural, historical, economic and social context. External pressures or crises, countries will adopt different policies to solve the problem.

The research framework of historical institutionalism explains why countries have policy errors and policy deviations in the process of institution introduction or innovation, and has played a very good inspiration role for monitoring and correcting government policies. This viewpoint makes historical institutionalism have a comparative advantage in policy study, which can effectively explain the differences between the sustainability of a country's policy path and country's policy. ${ }^{1}$

Through the above brief description of the theory of historical institutionalism, this paper intends to explain the following questions: 1 . Search for the basic elements behind the financial institution of each country, that is, the reasons and relations between different countries and regions in promoting inclusive finance; 2. Path dependence will lead to the self-reinforcement of China's inclusive finance in the transition process, what impact will it have?

\section{International case description}

As far as the current practice is concerned, the financial system still does not cover large financial needs in both developed and developing countries. The "Financial exclusion" is a commonly occurred phenomenon. However, the emergence of this phenomenon is based on the profit-seeking character of the financial system itself and market failure caused by the inevitable negative external

${ }^{1}$ Li Xiufeng. The persistent characteristics and restrictive functions of institutions: an Exploration of the Research Framework of Historical institutionalism in Public Policy [J]. China Administration, 2013 (10): 77 - 82. 
effect. According to the World Bank's Global Financial Development Report, "In recent years, about 50 countries have established formal indicators and targets for financial inclusion." Although these reforms and efforts are carried out through international networks such as the global financial inclusion partnership and financial inclusion alliance, and limited by the unique geographical, ethnic, cultural and other factors of each region, the process of learning from the excellent case experience to promote inclusive financial work more and more complicated.

\subsection{Bangladesh: Inclusive initiatives led by agricultural credit}

In the development of inclusive finance, the Bangladesh government concentrated on the support and intervention of agricultural credit. As one of the main sectors of the Bangladeshi economy, agriculture is critical to meeting the country's challenge to achieving self-sufficiency in food production and ensuring food security, reducing rural poverty and promoting sustainable economic development. The Bangladeshi agricultural sector has made significant contributions to achieving food sufficiency and job creation. Agricultural credit is one of the key factors for sustainable agricultural development and plays an important role in promoting agricultural transformation and increasing farmers' participation in the production process.

Given the importance of banking financing in agriculture for promoting inclusive growth in Bangladesh, the Bank of Bangladesh has developed an agricultural and rural credit policy that sets the fiscal year's agricultural credit spending target to promote financial inclusion, giving priority to marginal areas and farmers. The goal of this program is to expand the scope of agricultural credit and financial inclusion by using information technology to extend banking services to rural areas, and to mitigate the risks of poor people due to economic shocks or natural disasters. The results show that the Agricultural Credit Guarantee Program Fund and the government's allocation of funds to agriculture have had a significant positive impact on agricultural productivity.

\subsection{Mexico: Mexican banking reform}

After the Mexican peso crisis in 1994, the Mexican banking industry received government bailouts and a series of reforms. In the early 21st century, the Mexican banking industry opened up to foreign investment and began to provide specific activities for the sector. State-owned banks, which previously played an important role, are gradually out of touch with retail consumers. ${ }^{2}$ Table 1 shows a series of inclusive measures formulated by the Mexican government after the year of microfinance. Guided by policy signals, the banking system gradually shifts its business focus to help government departments achieve more detailed inclusive goals.

Table 1. Inclusive financial behavior led by the Mexican government

\begin{tabular}{l|l|l|l}
\hline Time & \multicolumn{1}{|c|}{ Main body } & \multicolumn{1}{|c}{ Dominant behavior } & \multicolumn{1}{c}{ Goal } \\
\hline 2005 & $\begin{array}{l}\text { Federal government } \\
\text { of Mexico }\end{array}$ & $\begin{array}{l}\text { Formulate the National } \\
\text { Development Plan 2007-2012 } \\
\text { and Ne National Development } \\
\text { the } \\
\text { Finance Plan 2008-2012 } \\
\text { Setting national targets of } \\
\text { achieving inclusive finance by } \\
\text { 2020 and }\end{array}$ & $\begin{array}{l}\text { Promote the reform of the banking } \\
\text { system and require banks to take } \\
\text { the lead in providing diversified } \\
\text { financial services to the public }\end{array}$ \\
\hline 2007 & $\begin{array}{l}\text { Sentral Bank and } \\
\text { Commission } \\
\text { Mexico }\end{array}$ & $\begin{array}{l}\text { Incorporate the establishment } \\
\text { of a "sound Pratt \& Whitney } \\
\text { Banking System" into its } \\
\text { scope of functions }\end{array}$ & $\begin{array}{l}\text { Distribute social benefits through } \\
\text { electronic payments, open mobile } \\
\text { payment deposit account and } \\
\text { handle business for free }\end{array}$ \\
\hline
\end{tabular}

\footnotetext{
${ }^{2}$ Ana Georgina Marín,Rainer Schwabe,Bank Competition and Financial Inclusion: Evidence from Mexico[J]. Springer Science, 2018.11

${ }^{3}$ Chen Yucheng. The present situation and comparative analysis of inclusive finance about domestic and overseas[J]. New economy, 2016 (11): 64.
} 


\begin{tabular}{|c|c|c|c|}
\hline 2011 & $\begin{array}{l}\text { Federal government } \\
\text { of Mexico }\end{array}$ & $\begin{array}{l}\text { Signed the Maya Declaration } \\
\text { adopted by the Inclusive } \\
\text { Finance Alliance and } \\
\text { established the National } \\
\text { Committee of Inclusive } \\
\text { Finance }\end{array}$ & $\begin{array}{l}\text { Formulating and implementing } \\
\text { inclusive financial policies at the } \\
\text { federal, state, prefecture-level and } \\
\text { municipal levels, and promoting } \\
\text { the necessary reform of the } \\
\text { inclusive financial regulatory } \\
\text { framework } 4\end{array}$ \\
\hline
\end{tabular}

Despite the recent growth in the banking sector in Mexico, the penetration rate of deposit accounts remains low. The World Bank's Global Financial Index (2012) survey found that only $27 \%$ of adults in Mexico have accounts in formal financial institutions. Based on this, the government has promoted the competitiveness of banks as a starting point to stimulate the autonomy of banking institutions. It is expected to increase the market share of bank accounts under the influence of market mechanisms to promote inclusive finance (see in Table 2).

Table 2. Market-based inclusive financial assistance behavior

\begin{tabular}{c|l|l}
\hline Main body & \multicolumn{1}{|c}{ Auxiliary behavior } & \multicolumn{1}{c}{ Goal } \\
\hline \multirow{3}{*}{ Market } & $\begin{array}{l}\text { Add mobile banking, non-banking } \\
\text { agents or correspondents }\end{array}$ & $\begin{array}{l}\text { Reduce barriers to entry and } \\
\text { increase the competitiveness of the } \\
\text { local banking market }^{5}\end{array}$ \\
\cline { 2 - 3 } & Support new technologies & $\begin{array}{l}\text { Make it easier for people to enter } \\
\text { the financial system }\end{array}$ \\
\hline
\end{tabular}

The implementation of the joint guarantee microfinance by the Compartamos Bank of Mexico has been a great success, effectively reducing the moral hazard and adverse selection issues. The success of Compartamos Bank is neither because of monopoly nor entirely depends on the business model: Compartamos Bank's pursuit for the profit maximization has led to a significant reduction in its operating costs; it has effectively used dynamic incentives to increase and adjust the average borrowing balance of the bank's borrowers; in addition, the Christ Military Order owns a large stake of the Compartamos Bank. The bank's success is inextricably linked to the religious group Christ Military Order. In a catholic country like Mexico, the religious connections between borrowers play a role in social capital to maintain a low loan default rate.

\subsection{Turkey: Non-commercial financial inclusive strategy under state intervention}

Turkey's experience of financialization during the neoliberal period demonstrates the critical role played by the state and public debt. In the late 1980s, the ruling party was committed to promoting financial liberalization. Capital account liberalization in 1989 provided space for capital flows, along with loose taxes and non-prudential regulation of the financial sector, which gradually exacerbated the commercialization of public services and led to serious financial crises. After the financial sector crisis of 2001, the Turkish banking industry reorganized and strengthened its regulatory requirements, and its focus has shifted to funding households, which has stimulated a substantial increase in consumer credit and has prompted many poor people to enter the formal financial sector. Increased household debt and credit expansion are among the triggers of Turkey's financial inclusive strategy, and one of the factors that the restructured banking industry hopes to absorb previously financially excluded social sectors.

In 2014, the Turkish political authorities formulated a financial inclusion strategy, strengthened the reform and division of labor of state institutions, carried out financial education and literacy, and supported innovation in new financial products and financial services. Despite the lack of a complete legal framework for microfinance institutions, the experience of microfinance can be considered a

\footnotetext{
${ }^{4}$ Research Group of inclusive Finance Department of China Banking Regulatory Commission. Experience and Enlightenment of developing inclusive Finance in Mexico and Brazil[J].China Rural Finance, 2016 (12): 78.

5 Assunçao, Eliminating entry barriers for the provision of banking services: Evidence from 'banking correspondents' in Brazil[J]. Journal of Banking and Finance, 2013,37(8), 2806 - 2811.
} 
state-led business. For example, the SME development organization supports small businesses by providing preferential repayment terms; The Turkish provincial administration and the municipal government provide microcredit to poor people such as women, self-employed or small businesses.

\section{Theoretical explanation: Path dependence under institutional change}

\subsection{International Inclusive Finance Case Path Dependence Analysis}

From the "2005 International Year of Microcredit" to the widespread application of the inclusive financial system, the concept, beneficiaries, implementation goals and means of inclusive finance occurred subtle influence in the socio-economic development, social structural changes and cultural conflicts and integration, and achieved different levels of inheritance and development. "Changes in national institutions or countries come either from learning about other institutions, responding to new information, or from the pressure of institutions arising from the accumulation of domestic critical factors." as macroscopically long as institutional reforms, the progress made in different countries or the dilemmas faced by them are results of all the government departments learning from each other and making positive response to the goal of helping the poor. From the perspective of the path dependence of the development of inclusive finance, the impact of accepting economic people, making them play their own functions to promote inclusive coverage is very weak, so inclusive finance should adapt to the new situation and self-demodulation must be an open state, a gentle and gradual advancement of the government, financial institutions, and industry sectors in conjunction with changes in the institutional framework and social needs.

Inclusive finance is a positive attempt in the global neoliberal transformation. It also provides an inclusive development framework for trying to empower poor human rights. The inclusiveness here is to help the poor in two ways: Guiding their actions and choices through mainstream financial institutions, and providing new markets or lending institutions. However, subjected to influence of multiplicity and ambiguity, this concept does not clearly carry out a set of policies and strategies to improve the level of financial inclusion, which only propose a legally regulated, non-political framework (world bank, 2014). ${ }^{7}$ Because institutional structures are a mixture of social struggles and competing political projects, these idealized concepts do not always match actual strategies and action plans. The particularity of history appears in the form and mechanism of a particular environment, and if did not planned, these forms and mechanisms will be modified. ${ }^{8}$ Because the role of the state and non-governmental organizations is different, and the inclusive finance itself is greatly affected by the nature of the financial system, emerging markets, existing financial infrastructure, access to financial services, and the profitability of the entire sector. The degree of benefits differs in the development of specific services in countries.

Take Bangladesh as an example. Such a long-established agricultural country, the primary object of inclusive finance is farmers. The Bangladesh government has intervened in financing agriculture for the sake of maintaining stable agricultural development. However, the agricultural credit policy support has already been carried out as early as the "microfinance year" proposed, and it is just that this government action is more inclusive. More fully. In the past four decades, the Bank of Bangladesh has made considerable progress in mobilizing deposits, increasing assets and expanding service coverage, so this can be a benchmark for developing countries seeking to be inclusive.

The success of Compartamos Bank of Mexico has become a model for many developing countries to follow in the development of microfinance model, but the results are not significant. Without understanding the situation of Mexico and its credit market, the effectiveness of its business model will have lots of limitations. For example, these countries have neglected that religion played an

\footnotetext{
${ }^{6}$ Zhao Hui, Zhu Lingjun. From the perspective of new institutionalism, historical institutionalism and its basic characteristics [J]. Social Science Research, 2003 (4): 24-28.

7 World Bank. (2014). Global financial development report: Financial inclusion. Washington DC: The World Bank.

8 Ali Riza Güngen,Financial Inclusion and Policy-Making: Strategy, Campaigns and Micro-credit,NEW POLITICAL ECONOMY, 2018
} 
extremely important role in the social network of the microfinance market in Mexico, which ensured a higher loan repayment rate, which also made the financial sustainability of Compartamos Bank possible. While in other developing countries, once the credit cannot be guaranteed, the loan cannot be effectively repaid, which certain means that this measure is not in line with the national conditions.

The Turkish case has a characteristic: Due to the intervention and supervision of the state organization, the microfinance sector presents a non-commercial character, and the country has played an active role in the financial transformation of Turkey, which has provided greatly policy support to the financial sector. Since Turkey's microfinance is still not commercialized and is not affected by the motives of the international community, it is unlikely that the country will expand microfinance into a formal government policy and open this field to the for-profit institutions. Broadly speaking, the Turkish government is more like setting this action as a performance standard, so that the financial inclusive strategy can be in line with the international policy agenda.

\subsection{China's inclusive financial case path dependence analysis}

In the inclusive financial policy, sometimes there is an inefficiency state, that is, the current institution presents a self-reinforcing lock-up phenomenon. The institution provides incentives for actors to choose to continue to maintain the institution or change the institution by weighing the expected benefits. According to the cognitive distance theory, financial institutions have more voice and initiative over their own sustainable development than the central government. However, at present, China's inclusive financial policy still reflects the state's dominance and shows a strong institutional inertia. There is no essential shift of the institution. This study intends to analyze the path dependence of the inclusive financial policy from the perspective of the government, which is a key actor.

Due to the important position of finance in the development of the country's society, coupled with China's long-term highly concentrated planned economic system, the government has always shown stricter macroeconomic regulation or direct intervention on financial development. Affected by the "Financial Constraint Theory", the government always allocates resources through various banking policies, artificially adjusts financial markets, and achieves specific policy intentions to encourage consumers to use financial services. With the introduction of inclusive financial policies, it means that the beneficiaries have shifted their focus from the banking industry to new financial institutions and small and micro enterprises. The changes in the new financial ecology and the development of financial industry innovation trends will undoubtedly weaken the government's financial macrocontrol ability of the industry. After more than 10 years exploration, China's financial supervision system has formed a separate financial supervision structure of "One bank, three supervisory committees", and because of the vague understanding of the financial management concept, the current compliance supervision still remains at a stage of shallow-level, static administrative. Even though the government and the international community are striving to create a more inclusive environment for financial innovation, the safety regulation often results at the expense of efficiency, which has prompted some financial institutions to deviate from inclusive financial policies. It is precisely because the old institution provides a predictability of behavior, but the new institution does not always provide such predictability, and then path dependence occurred. Therefore, it is difficult for the inclusive finance with the meaning of "charity" to make continuous progress. The state-led financial supervision system has existed for a long time. Therefore, in order to further promote the inclusive finance, the government needs to design more auxiliary institutions to help form the institutional matrix. Of course, this costs a lot of time. As the government can neither eliminate the "short-sighted" nor "profit-seeking" characteristics of financial institutions, it needs institutional cooperation to make people believe that the new system can provide the same or more expected benefits compared with the old system. 


\section{Inspiration}

Affected by historical institutionalism, the characteristics of the basic organizational structure related institution of the society formed in history will have an impact on specific policy outcomes, and ultimately lead to policy differences between countries, which makes us face the challenge of how to transform and localize the foreign experience while introducing it.

At present, China's inclusive finance still follows the top-down development path. We must strive to turn such a compulsory strategic measure into a cause of active participation and exploration by the whole society. At the stage of "Opening the last mile of inclusive finance", the government must activate the influx of various social resources, so that the various agencies of the industry can cooperate with each other, give full play to the initiative and unique advantages, avoid free-riding behavior, and make progress together through scientific and technological strength.

Adhere to the "Two-wheel drive" and take the road of structural reform of the financial supply side of "Government-led" and "Market-led", not only to give full play to the guiding role of the market mechanism, realize the sustainable management of inclusive finance in business, but also to create a relaxed policy environment and better play the role of government supervision. When cultivating and guiding inclusive finance, the government should implement differentiated regulatory measures for inclusive financial institutions according to the business, products and services of different financial institutions, so that new financial institutions can enjoy the benefits of policies such as adjustment of registered capital and tax reduction and exemption, and give full play to their innovative role, at last, form a financial market with rich levels and structures. In addition, the government should correctly handle private informal finance, standardize new inclusive financial services, and guard against "excessive debts". This is an important task for the development of inclusive finance, and it is also a problem that we need to solve in the long run.

\section{References}

[1] Li Xiufeng. The persistent characteristics and restrictive functions of institutions: an Exploration of the Research Framework of Historical institutionalism in Public Policy [J]. China Administration, 2013 (10): 77 -82.

[2] Ana Georgina Marín,Rainer Schwabe,Bank Competition and Financial Inclusion: Evidence from Mexico[J]. Springer Science,2018.11.

[3] Chen Yucheng. The present situation and comparative analysis of inclusive finance about domestic and overseas[J]. New economy, 2016 (11): 64.

[4] Research Group of inclusive Finance Department of China Banking Regulatory Commission. Experience and Enlightenment of developing inclusive Finance in Mexico and Brazil[J].China Rural Finance, 2016 (12): 78.

[5] Assunçao, Eliminating entry barriers for the provision of banking services: Evidence from 'banking correspondents' in Brazil[J]. Journal of Banking and Finance,2013,37(8), 2806-2811.

[6] Zhao Hui, Zhu Lingjun. From the perspective of new institutionalism, historical institutionalism and its basic characteristics [J]. Social Science Research, 2003 (4): 24-28.

[7] World Bank. (2014). Global financial development report: Financial inclusion. Washington DC: The World Bank.

[8] Ali Riza Güngen,Financial Inclusion and Policy-Making: Strategy, Campaigns and Microcredit,NEW POLITICAL ECONOMY, 2018. 